\title{
Conplastic Strains for Identification of Retrograde Effects of Mitochondrial DNA Variation on Cardiometabolic Traits in the Spontaneously Hypertensive Rat
}

\author{
Michal PRAVENEC ${ }^{\mathbf{1}}$, Jan ŠILHAVÝ ${ }^{1}$, Petr MLEJNEK ${ }^{\mathbf{1}}$, Miroslava ŠIMÁKOVÁ ${ }^{\mathbf{1}}$, \\ Tomáš MRÁČEK ${ }^{1}$, Alena PECINOVÁ ${ }^{1}$, Kateřina TAUCHMANNOVÁ ${ }^{1}$, Martina HÜTL ${ }^{2}$, \\ Hana MALÍNSKÁ ${ }^{2}$, Ludmila KAZDOVÁ ${ }^{2}$, Jan NECKÁŘ ${ }^{1}$, František KOLÁŘ ${ }^{1}$, \\ Jitka ŽURMANOVÁ ${ }^{3}$, Jiří NOVOTNÝ ${ }^{3}$, Josef HOUŠTĚK ${ }^{1}$
}

${ }^{1}$ Institute of Physiology of the Czech Academy of Sciences, Prague, Czech Republic, ${ }^{2}$ Institute for Clinical and Experimental Medicine, Prague, Czech Republic, ${ }^{3}$ Department of Physiology, Faculty of Science, Charles University, Prague, Czech Republic

Received June 7, 2021

Accepted August 10, 2021

\begin{abstract}
Summary
Mitochondrial retrograde signaling is a pathway of communication from mitochondria to the nucleus. Recently, natural mitochondrial genome (mtDNA) polymorphisms (haplogroups) received increasing attention in the pathophysiology of human common diseases. However, retrograde effects of mtDNA variants on such traits are difficult to study in humans. The conplastic strains represent key animal models to elucidate regulatory roles of mtDNA haplogroups on defined nuclear genome background. To analyze the relationship between mtDNA variants and cardiometabolic traits, we derived $a$ set of rat conplastic strains (SHR-mt ${ }^{\mathrm{BN}}, \mathrm{SHR}-\mathrm{mt}^{\mathrm{F} 344}$ and SHR-mt ${ }^{\mathrm{LEW}}$ ), harboring all major mtDNA haplotypes present in common inbred strains on the nuclear background of the spontaneously hypertensive rat (SHR). The BN, F344 and LEW mtDNA differ from the SHR in multiple amino acid substitutions in protein coding genes and also in variants of tRNA and rRNA genes. Different mtDNA haplotypes were found to predispose to various sets of cardiometabolic phenotypes which provided evidence for significant retrograde effects of mtDNA in the SHR. In the future, these animals could be used to decipher individual biochemical components involved in the retrograde signaling.
\end{abstract}

\section{Key words}

Mitochondrial DNA - Conplastic strains - Spontaneously hypertensive rat $\bullet$ Glucose and lipid metabolism • Cardiac traits

\section{Corresponding author}

Michal Pravenec and Josef Houštěk, Institute of Physiology,
Czech Academy of Sciences, Vídeňská 1083, 14220 Prague, Czech Republic. E-mail: michal.pravenec@fgu.cas.cz, josef.houstek@fgu.cas.cz

\section{Introduction}

Mitochondria regulate a number of key metabolic pathways including oxidative phosphorylation, beta-oxidation of fatty acids, tricarboxylic acid cycle, biosynthesis of heme as well as some phospholipids. Taking into account this broad range of pathways, it does not come as a surprise that mitochondrial dysfunction has been recognized either as cause or modulator in numerous human pathologies. Yet another level of complexity stems from the fact, that mitochondria contain their own (mtDNA), and associated proteosynthetic apparatus. Mammalian mtDNA harbors 13 proteincoding genes, 22 transfer RNA (tRNA) genes, and 2 ribosomal RNA (rRNA) genes. Rare mitochondrial mutations affecting mainly high-energy demand tissues (e.g. brain, heart or skeletal muscle), are associated with specific syndromes such as Leber's Hereditary Optic Neuropathy (LHON), Myoclonic Epilepsy with Ragged Red Fibers (MERRF) or Maternally Inherited Diabetes and Deafness (MIDD) (Lott et al. 2013). Given the relatively high mtDNA sequence variation, about 100-fold higher than the nuclear genome (Song et al. 
2005), potential role of mtDNA background as modulator of susceptibility towards development of common diseases associated pathologies attracts considerable attention. For example, it has been suggested that common variants in human mtDNA were subject of natural selection and adaptation to cold climates. While some variants conferred adaptation to cold climates, in modern societies they may predispose towards development of type 2 diabetes (Mishmar et al. 2003, Ruiz-Pesini et al. 2004). Other studies have indicated that the inheritance of type 2 diabetes may be biased toward the maternal lineage (Alcolado et al. 2002) and that mitochondrial DNA mutations might be involved in $>20 \%$ of cases of type 2 diabetes (Sun et al. 2003). Discrepant results were obtained by association analyses of mtDNA variability with disease phenotypes. Early attempts failed to detect specific association between mtDNA variants and diabetes (Saxena et al. 2006). On the other hand, recent meta-analysis of the multiple mtDNA association studies conducted until 2016, encompassing 53,975 patients and 63,323 controls, found that some mtDNA variants affect specific, primarily neurological phenotypes, while others have pleiotropic effects (Marom et al. 2017). In phenome wide association studies (PheWAS), other investigators screened for the association between genetic variation in mtDNA and a wide range of traits in over 11,000 African Americans. Through this approach, they identified 2 mtDNA SNPs significantly associated with total cholesterol and type 2 diabetes (Mitchell et al. 2014). In addition, CHARGEmtDNA+ consortium performed analysis on 45 cohorts with a total of 196,967 individuals and identified two significant common variants in MT-ATP6 associated with waist-to-hip ratio and one in the D-loop associated with glucose (Kraja et al. 2019).

However, neither epidemiological evidence nor case/control studies alone are sufficient to establish the role of mtDNA sequence variation as a risk factor in the development of common diseases. For example, effects of maternal environment or imprinting may contribute to matrilineal transmission patterns of the phenotypes of interest. Variation in copy number and tissue distribution of heteroplasmic mtDNA variants can have unpredictable phenotypic consequences. Even homoplasmic mtDNA variants may present wide phenotypic spectrum through their complex interactions with nuclear genes or environmental factors that are difficult to control in humans. Substitution of different mitochondrial genomes on the same nuclear genetic background in conplastic strains provides a way to unambiguously isolate effects of the mitochondrial genome on complex traits independent of variation in the nuclear genome and other confounding factors such as heteroplasmy, imprinting phenomena and environmental factors.

Conplastic strains are inbred strains with identical nuclear genomes that differ only in their mitochondrial genomes. Primarily, they have been produced in mice (Yu et al. 2009) or rats (Kumarasamy et al. 2013, Pravenec et al. 2007) but also other conplastic model species, such as Drosophila (Aw et al. 2018) can be found in the literature. Mouse common inbred strains show relatively little variability in mtDNA ( $\mathrm{Yu}$ et al. 2009, Goios et al. 2007), with remarkable difference represented by NZB strain, which also enabled systematic exploration of mtDNA on observed metabolic phenotypes and associated retrograde signaling pathways (LatorrePellicer et al. 2016). In this regard, rat inbred strains, which display considerably higher variability (see below), represent more promising experimental models for the study of mitonuclear epistasis.

Since mitochondria are inherited maternally, the typical process of conplastic strain generation involves sequential backcrossing of females from the donor strain to males of the recipient strain for 10 and more generations. By the $10^{\text {th }}$ backcross generation, nuclear genomes of conplastic and recipient strains will be nearly identical $\sim 99.8 \%$ (Fig. 1). Recently, pronuclear transfer into oocytes containing different mtDNA background has been used as a strategy to prepare conplastic mouse models (Kesterson et al. 2016) and the first study utilizing this model have already been published (Dunham-Snary et al. 2018).

\section{Spontaneously hypertensive rat}

The spontaneously hypertensive rat (SHR) is the most widely used animal model of human essential hypertension and left ventricular hypertrophy and under special environmental conditions (for instance, when fed a high-fructose or folate-deficient diets) also develops disturbances of lipid and glucose metabolism, i.e. the hallmarks of metabolic syndrome (Pravenec et al. 2014). Similar to humans, these hemodynamic and metabolic disturbances in the SHR are determined multifactorially. Phenotyping of reciprocally derived female ( ${ }^{\top} \mathrm{SHR} x$ $\mathrm{BN}) \mathrm{F} 1$ hybrids that inherited the BN mtDNA versus female ( ${ }^{A} \mathrm{BN} x$ O SHR)F1 hybrids that inherited the SHR mtDNA on identical (BN x SHR)F1 nuclear genome, 


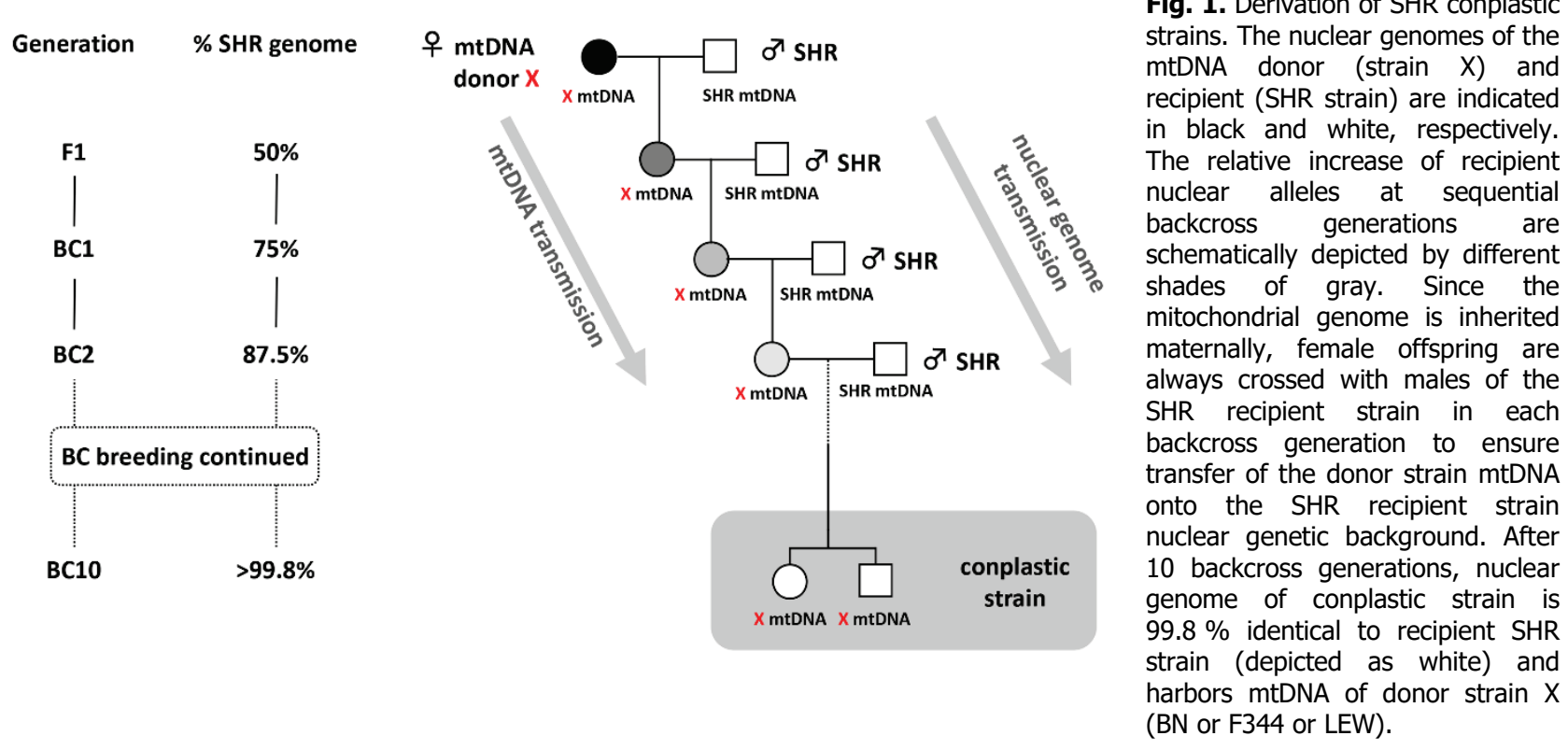

demonstrated maternal transmission bias in several known metabolic risk factors for type 2 diabetes. These findings supported the hypothesis, that variability between BN and SHR mtDNA is responsible for the observed phenotypes and triggered the generation of conplastic strains on SHR nuclear background (Pravenec et al. 2007).

\section{Mitochondrial DNA sequence variation}

Genotyping 43 common rat inbred strains identified a subset of 16 polymorphisms that defined four major haplotype groups among rat inbred strains that are represented by BN (Brown Norway), F344 (Fisher 344), LEW (Lewis), and SHR strains (Pravenec et al. 2007). To analyze the contribution of mtDNA variation on complex pathophysiological traits in the SHR, we derived conplastic strains with those four mtDNA haplotypes, namely parental SHR-mt ${ }^{\mathrm{SHR}}$, SHR-mt ${ }^{\mathrm{BN}}$ (currently at N47 backcross generations), SHR-mt ${ }^{\mathrm{F} 344}$ (N42) and SHR-mt ${ }^{\text {LEW }}$ (N42) strains (Pravenec et al. 2007, Houštěk et al. 2012, Houštek et al. 2014).

\section{BN mtDNA haplotype}

$\mathrm{BN}$ represents one of the most genetically distant inbred strains to SHR and this manifested also in the mtDNA sequence. Comparison of the complete mtDNA sequences revealed polymorphisms of potential functional significance in seven of the $13 \mathrm{mtDNA}$ encoded proteins, namely cytochrome $c$ oxidase subunit I (COX1), ATP synthase subunit 6 (ATP6), ATP synthase subunit 8 (ATP8), cytochrome $b$ (CYTB), NADH dehydrogenase subunit 2 (ND2), NADH dehydrogenase subunit 4 (ND4), and NADH dehydrogenase subunit 6 (ND6) (Table 1). In addition, there were also polymorphisms in five of the 22 transfer RNA (tRNA) genes and both of the ribosomal RNA (rRNA) genes (Pravenec et al. 2007).

Some of these substitutions are located within 0-3 amino acid residues of mutation sites known to be associated with human disorders (see Lott et al. 2013) including exercise intolerance and LHON. Of the seven variants affecting five tRNA genes, three are located within $4 \mathrm{bp}$ of human mutation sites associated with mitochondrial encephalopathy and focal segmental glomerulosclerosis (Pravenec et al. 2007). Five of the BN variants in $m t-C o 1, m t-A t p 8, m t-N d 4, m t-N d 6$, and $m t-C y b$ genes were not found in any of the other inbred strains. Indeed, several of the variants involve residues that are relatively conserved among multiple species. Of particular interest is that the $\mathrm{BN}$ rat along with the guinea pig and macaque are the only mammals tested that have a leucine at position 2 of COX1 (Table 1). The SHR and 40 other rat strains as well as the mouse, cow, dog, human, chimpanzee, opossum, and chicken have phenylalanine in this position, whereas zebrafish and stickleback have either threonine or alanine (Pravenec et al. 2007).

\section{LEW mtDNA haplotype}

In contrast to the comparisons of the SHR mitochondrial genome with the $\mathrm{BN}$, there are only 
a small number of differences between the SHR and LEW mitochondrial genome, likely because of the common Wistar origin of the SHR and LEW strains. Altogether, four amino acid substitutions were found in the $m t-N d 2, m t-N d 4$, and $m t-N d 5$ genes. No variants were found in mitochondrial tRNA or rRNA genes between the SHR and LEW strains. The mtDNA sequence of the LEW/Ipcv strain was identical to previously published mtDNA sequence of the LEW/NCrlBR strain (Kumarasamy et al. 2010). Two mutations in the $m t-N d 4$ (Thr356Ala and Leu419Pro) are close to known pathological mutations associated with exercise intolerance and diabetes mellitus in humans. The Thr356 variant in the SHR appears unique since all other species tested, including human, bovine, dog and fugu fish have alanine in this position (Houštěk et al. 2012).

\section{F344 mtDNA haplotype}

In case of F344 mtDNA, in accordance with published sequence (Schlick et al. 2006), 11 amino acid substitutions in mtDNA protein coding genes (three in $m t-N d 2$, four in $m t-N d 4$, one in $m t-C o 1$, one in $m t-C o 2$, one in $m t-A t p 6$, and one in $m t-C y t b)$ were revealed. Seven differences in protein-coding genes were located close to mutations associated with known human pathologies: two of them are in $m t-N d 2$ gene (LHON, insulin resistance), three in $m t-N d 4$ gene (chronic progressive external ophthalmoplegia, exercise intolerance, and cancer), one in $m t-C o 2$ gene (maternally inherited deafness), and one in $m t$-Cytb gene (LHON). In two cases, the amino acid substitutions occurred at positions associated with disease phenotypes in humans (Ser150Asn in $m t-N d 2$ and Val165Ile in $m t$-Co2). Furthermore, Val165Ile substitution in $m t-C o 2$ represents exactly the same substitution as observed for maternally inherited deafness in human patients. However, no significant differences in auditory brainstem response (ABR) and distortion product otoacoustic emissions (DPOE) were observed between SHR- $\mathrm{mt}^{\mathrm{F} 344}$ conplastic and SHR strain (Pravenec, Syka et al. unpublished results) suggesting species specific effects of Val165Ile substitution in $m t-\mathrm{Co} 2$ gene on hearing.

There were also seven nucleotide substitutions affecting five tRNA genes. Compared with human mtDNA, five of these variations were located very close to described positions of human pathogenic mutations.

Table 1. Summary of amino acid differences in mtDNA encoded OXPHOS protein subunits present in SHR derived rat conplastic strains. No change versus SHR mtDNA genome is indicated by dash. mtDNA of BN, F344, and LEW origin differ from SHR mtDNA in 15, 11, and 4 amino acid substitutions, respectively.

\begin{tabular}{lccccc}
\hline Gene & AA No. & SHR & BN & F344 & LEW \\
\hline$m t-N d 2$ & 18 & Ala & Val & - & Val \\
& 150 & Ser & Asn & Asn & - \\
& 244 & Ala & Thr & - & - \\
& 265 & Thr & Ala & Ala & - \\
$m t-N d 4$ & 304 & Met & Leu & Thr & - \\
& 23 & Thr & Ile & Ile & - \\
& 356 & Thr & - & Ala & Ala \\
& 393 & Ile & Ala & Met & - \\
Mt-Nd5 & 401 & Ile & - & Val & Val \\
$m t-N d 6$ & 405 & Met & Ile & - & - \\
& 37 & Thr & - & - & Ala \\
$m t-C y t b$ & 30 & Phe & Leu & - & - \\
& Val & Ile & - & - \\
$m t-C o 1$ & 139 & Asn & Asp & Asp & - \\
$m t-C o 2$ & 214 & Val & Ile & - & - \\
$m t-A t p 6$ & 334 & Phe & Leu & - & - \\
$m t-A t p 8$ & 2 & Asn & - & Asp & - \\
\hline & 406 & Val & - & Ile & - \\
& 165 & Lys & Glu & Glu & - \\
& 35 & Ile & Thr & - & - \\
\hline
\end{tabular}


These pathologies include severe diseases like myoclonic epilepsy and ragged red muscle fibers, mitochondrial encephalopathy, cytopathy and myopathy, focal segmental glomerulosclerosis, lactic acidosis, and left ventricular noncompaction cardiomyopathy (LVNC). The rRNA mtDNA genes displayed also numerous differences between F344 and SHR strains. In the 12S rRNA, there are only two one-nucleotide changes, but there are multiple sequence differences in the 16S rRNA. Mutations in positions close to observed polymorphisms in $12 \mathrm{~S}$ rRNA are in humans mostly associated with maternally inherited deafness. In contrast, mutations in 16S rRNA are in humans mostly associated with LVNC, Rett syndrome, myopathy, MELAS (Mitochondrial Encephalopathy, Lactic Acidosis, and Stroke-like episodes) and with Alzheimer's and Parkinson's diseases (Houštěk et al. 2014).

\section{Function of mitochondrial OXPHOS apparatus}

SHR-mt ${ }^{B N}$ conplastic strain

Analysis of enzyme activities of selected respiratory chain complexes revealed significantly lower activity of cytochrome $c$ oxidase (COX, complex IV) in the SHR-mt ${ }^{\mathrm{BN}}$ animals. In contrast, there were no strain differences in succinate cytochrome $c$ oxidoreductase (SCCR, complex II + III), NADH cytochrome $c$ oxidoreductase, rotenone sensitive (NCCR, complex I + III), or citrate synthase (CS) (Fig. 2). This led to suggestion, that the rare variant in the $m t-C o l$ gene observed in the $\mathrm{BN}$ haplogroup is causative for the observed differences. This was accompanied by decreased COX content as we observed a significant decrease in the quantity of both mtDNA encoded COX2 and nuclear-encoded COX4 subunits of cytochrome c oxidase (complex IV) and a tendency towards decreased levels of the COX1 subunit in SHR-mt ${ }^{\mathrm{BN}}$ animals. In agreement with enzyme activities, levels of other respiratory chain complexes (complexes I, III, or V) were not changed in the conplastic strain. We did not detect any reductions in mtDNA copy number relative to genomic DNA content or any reductions in tissue CS activity between the strains (Pravenec et al. 2007).

SHR-mt ${ }^{L E W}$ conplastic strain

Analysis of the OXPHOS system in SHR-mt ${ }^{\mathrm{LEW}}$ showed tissue-specific effects, suggesting a downregulation of the content and activities of
OXPHOS complexes in muscle and, to a lesser extent, in livers of the conplastic rats (Fig. 2).

Tissue content of OXPHOS complexes was analyzed by Western blot using selected representative subunits for individual complexes. In muscle of the SHR-mt ${ }^{\text {LEW }}$ conplastic strain, the specific content of all respiratory chain complexes was decreased (by 23-39\%), and this decrease was significant in the case of complexes I, II, IV, and V. Similar, but less pronounced decreases in SHR-mt ${ }^{\mathrm{LEW}}$ were found in the heart, with the decrease being significant in case of complexes III and V. The liver of SHR-mt ${ }^{\mathrm{LEW}}$ conplastic rats showed a significant decrease in the specific content of complex I, while complex II was increased. These changes in the OXPHOS system composition were not associated with detectable differences in the tissue content of adenine nucleotides AMP, ADP, and ATP or in the ATP/ADP ratio. Similar to the other SHR conplastic strains analyzed, we did not observe any reduction in mtDNA copy number in SHR-mt ${ }^{\mathrm{LEW}}$ strain (Houštěk et al. 2012).

SHR- $m t^{F 344}$ conplastic strain

In SHR-mt ${ }^{\mathrm{F} 344}$ rats, we observed a general tendency for decreases in OXPHOS enzyme-specific activities of NCCR, SCCR, COX, and CS. The decreases were more pronounced in heart and muscle than in liver (Fig. 2). Western blot analysis using monoclonal antibodies to selected marker subunits of individual enzyme complexes of the mitochondrial respiratory chain further revealed a decrease in several complexes in SHR-mt ${ }^{\mathrm{F} 344}$ conplastic rats. Based on their specific content per mg protein of tissue homogenate, complexes III and IV were significantly decreased in muscle and complexes I and II in heart, while in liver, complex I was decreased and complex II was increased. There were no significant differences in mtDNA copy number (Houštěk et al. 2014).

\section{Variation in metabolic traits}

SHR-mt ${ }^{B N}$ conplastic strain

Replacing the SHR mitochondrial genome with the BN mitochondrial genome promoted impaired glucose tolerance. In the SHR-mt ${ }^{\mathrm{BN}}$ conplastic strain, skeletal muscle glycogen content was significantly decreased compared to that in the SHR progenitor strain (Table 2). The ATP level in skeletal muscle of the SHR conplastic strain was significantly decreased compared to that in the SHR progenitor strain. These 

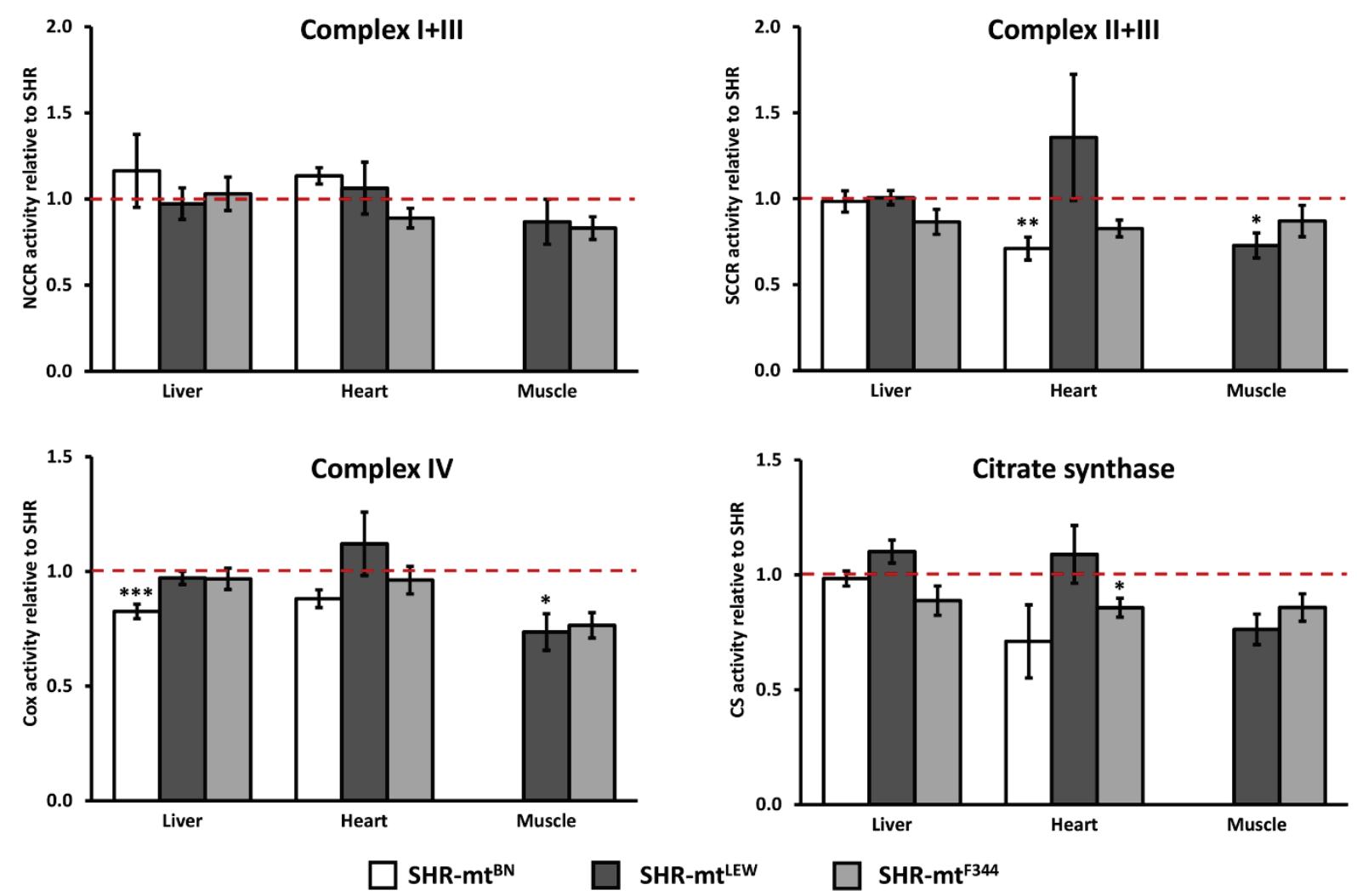

Fig. 2. Activity levels of NADH cytochrome $\mathrm{c}$ reductase (NCCR, Complex I+III), succinate cytochrome c reductase (SCCR, Complex II+III), cytochrome c oxidase (COX, Complex IV) and citrate synthase (CS) in liver, heart and muscle from the SHR-mt ${ }^{\mathrm{BN}}$, SHR-mt $\mathrm{t}^{\mathrm{LEW}}$ and SHR-mt ${ }^{\mathrm{F} 34}$ conplastic strains compared to SHR progenitor strain. All enzyme activities were expressed relative to activity of SHR progenitor strain set at 1. Original raw data were published in Pravenec et al. 2007, Houštěk et al. 2012 and Houštěk et al. 2014. Statistical significance $* \mathrm{P}<0.05, * * \mathrm{P}<0.01, * * * \mathrm{P}<0.001$.

Table 2. Metabolic phenotypes associated with transfer of major mtDNA haplotypes on SHR genetic background. $\uparrow$, $\downarrow$, and $\leftrightarrow$ symbols denote significantly increased, decreased, and not significantly different, respectively, values in conplastic strains when compared to the SHR. n.d. denotes not determined.

\begin{tabular}{lccc}
\hline & & SHR versus conplastic strains & \\
\cline { 2 - 4 } Traits & SHR-mt $^{\text {BN }}$ & SHR-mt $^{\text {LEW }}$ & SHR-mt $^{\text {F344 }}$ \\
\hline Body weight & $\downarrow$ & $\uparrow$ & $\leftrightarrow$ \\
Serum glucose & $\leftrightarrow$ & $\leftrightarrow$ & $\leftrightarrow$ \\
Serum insulin & $\leftrightarrow$ & $\leftrightarrow$ & $\leftrightarrow$ \\
Serum NEFA & $\leftrightarrow$ & $\uparrow$ & $\leftrightarrow$ \\
Serum triglycerides & $\leftrightarrow$ & $\leftrightarrow$ & $\downarrow$ \\
Skeletal muscle glycogen & $\downarrow$ & $\leftrightarrow$ & $\downarrow$ \\
Glucose during OGTT & $\uparrow$ & n.d. & $\leftrightarrow$ \\
Insulin during OGTT & $\uparrow$ & $\downarrow$ & $\downarrow$ \\
Basal glycogenesis & $\downarrow$ & $\leftrightarrow$ & $\downarrow$ \\
Insulin stimulated glycogenesis & $\leftrightarrow$ & $\downarrow$ & $\leftrightarrow$ \\
Basal lipogenesis & $\leftrightarrow$ & $\downarrow$ \\
Insulin stimulated lipogenesis & $\downarrow$ & $\leftrightarrow$ & $\leftrightarrow$ \\
\hline
\end{tabular}

results demonstrate that selective replacement of the mitochondrial genome of the SHR with the mitochondrial genome of the BN rat influences several major metabolic risk factors for type 2 diabetes (Pravenec et al. 2007).
SHR-mt ${ }^{L E W}$ conplastic strain

We found that glucose, insulin, and triglyceride levels were similar in the SHR-mt ${ }^{\mathrm{LEW}}$ conplastic and the SHR progenitor strain, and we did not detect any strain 
differences in glucose and insulin levels after oral glucose loading. However, SHR-mt ${ }^{\mathrm{LEW}}$ rats showed significantly increased levels of free fatty acids in serum. Similarly, serum free fatty acid levels were higher during the OGTT, which points towards reduced antilipolytic effects of insulin in conplastic animals. The mean body weight of SHR-mt ${ }^{\mathrm{LEW}}$ rats was significantly higher, however, there were no significant differences in relative weight of epididymal and subcutaneous fat or in relative liver weight, which suggests that the greater body weight in conplastic rats was not due to increased adiposity. In the SHR-mt ${ }^{\mathrm{LEW}}$ conplastic strain, glucose incorporation into skeletal muscle glycogen was significantly lower than in the SHR progenitor strain both before and after stimulation with insulin. In addition, the conplastic rats showed adipose tissue insulin resistance as judged by reduced insulin stimulated incorporation of glucose into adipose tissue lipids (Table 2) (Houštěk et al. 2012).

\section{SHR-mt ${ }^{F 344}$ conplastic strain}

The mean body weight of the conplastic strain was similar to the SHR strain. Serum glucose levels were similar between the SHR-mi ${ }^{\mathrm{F} 344}$ conplastic and the SHR progenitor strain, while the insulin concentrations tended to be higher in conplastic rats. During oral glucose tolerance tests (OGTT), conplastic rats showed glucose levels similar to SHR controls. On the other hand, insulin levels were significantly increased in conplastic rats after glucose loading, which suggests that SHR-mt ${ }^{\mathrm{F} 344}$ animals developed insulin resistance. Conplastic rats showed significantly reduced nonfasting serum triglyceride levels, with no change observed in the tissue triglyceride levels for liver, skeletal muscle, and heart. In the SHR-mt ${ }^{\mathrm{F} 344}$ conplastic strain, glucose incorporation into skeletal muscle glycogen was significantly lower than in the SHR progenitor strain both before and after stimulation with insulin. There were no significant differences in basal or insulin-stimulated incorporation of glucose into adipose tissue lipids between conplastic and control rats (Table 2) (Houštěk et al. 2014).

\section{Cardiac and hemodynamic function in conplastic strains}

\section{SHR-mt ${ }^{B N}$ conplastic strain}

No significant differences in radiotelemetrically measured arterial blood pressures were detected in SHR versus SHR-mt ${ }^{\mathrm{BN}}$ conplastic rats (Pravenec et al. unpublished results). Heart weight did not differ between the strains, but left ventricle normalized to body weight ratio was significantly higher in SHR-mt ${ }^{\mathrm{BN}}$ conplastic rats than in SHR controls (Neckár et al. 2017).

Replacement of mitochondrial genome of SHR with that of BN rats did not affect baseline myocardial tolerance to acute ischemia/reperfusion injury induced by coronary occlusion in open-chest rats. However, adaptation to cardioprotective regimen of chronic hypoxia resulted in a significantly more pronounced reduction of infarct size in SHR-mt ${ }^{\mathrm{BN}}$ rats than in progenitor SHR. In line with myocardial infarct sizelimiting effect, mitochondria isolated from hearts of chronically hypoxic rats of both strains were less sensitive to $\mathrm{Ca}^{2+}$-induced swelling. The maximum rate of mitochondrial swelling was significantly lower in SHR-m ${ }^{\mathrm{BN}}$ rats compared to the SHR (Neckár et al. 2017). This suggests that the mitochondrial genome modulates the cardioprotective effect of chronic hypoxia against ischemia/reperfusion injury by affecting the sensitivity of the mitochondrial permeability transition pore (MPTP) to opening.

Chronic hypoxia was associated with partially dissimilar changes in beta adrenergic receptors, monoamine oxidase A and some components of the antioxidant defense in the myocardium of SHR versus SHR-mt ${ }^{\mathrm{BN}}$ (Hahnová et al. 2018). These differences may contribute to more efficient cardioprotection conferred by chronic hypoxia in SHR-mt ${ }^{\mathrm{BN}}$ versus SHR possibly due to the hypoxia inducible factor-dependent pathway of the protein kinase $\mathrm{B} / \mathrm{glucose}$ transporters/hexokinase (Nedvědová et al. 2018). In rats chronically exposed to hypoxia, gene expression profiling suggested that greater cardioprotection in the SHR-mt ${ }^{\mathrm{BN}}$ conplastic strain compared to the SHR progenitor strain is associated with increased expression of transcripts related to energy metabolism, antioxidant response and mitochondrial dynamics (Nedvědová et al. 2019).

\section{SHR-mt ${ }^{\text {LEW }}$ conplastic strain}

There are limited published data, which would focus on detailed characterization of cardiometabolic phenotypes in SHR-mt ${ }^{\mathrm{LEW}}$ animals. When we telemetrically analyzed arterial blood pressure, we did not observe statistically significant differences between SHR and SHR-mt ${ }^{\mathrm{LEW}}$ conplastic rats (Pravenec et al. unpublished results). SHR and SHR-mt ${ }^{\mathrm{LEW}}$ strains did not differ in cardiac ischemic tolerance. As compared to SHR-mt ${ }^{\mathrm{BN}}$ animals, LEW mitochondrial DNA had no additional cardioprotective effect in spontaneously hypertensive rats adapted to chronic hypoxia (Cyprová et al. 2018). 
SHR-mt ${ }^{F 344}$ conplastic strain

There was no significant difference between SHR-mt ${ }^{\mathrm{F} 344}$ conplastic strain and SHR controls in arterial blood pressure and heart rates measured by telemetry. The weights of both heart ventricles normalized to body weight were significantly increased in SHR-mt ${ }^{\mathrm{F} 44}$ conplastic rats compared with SHR control. There were no echocardiographically detectable differences in left ventricle dimension and wall thickness between the two groups, except for the increased end-systolic diameter in conplastic rats. In addition, conplastic rats exhibited slight but significant impairment of fractional shortening, both at baseline and after stimulation with dobutamine compared with the SHR (Fig. 3) (Houštěk et al. 2014).

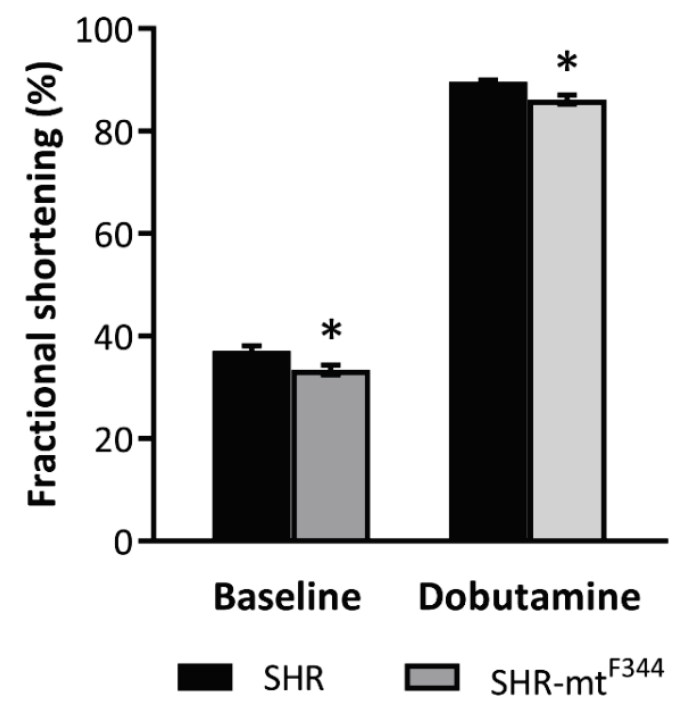

Fig. 3. Echocardiography assessment of fractional shortening in SHR-mt $\mathrm{t}^{\mathrm{F} 34}$ rats. Baseline as well as maximal values (after dobutamine) are shown.

\section{Conclusions}

In summary, we have found that inherited variation in mitochondrial genes encoding respiratory chain complexes can influence mitochondrial function, cardiac remodeling and function, glucose tolerance, and sensitivity of skeletal muscle and adipose tissue to insulin action. In future studies, conplastic strains might be used to analyze interactions between different mtDNA haplotypes and nuclear genes that may influence mitochondrial function. For instance, the SHR harbors mutations of Endog (endonuclease G) that predispose to left ventricular hypertrophy (McDermott-Roe et al. 2011), Wars2 (mitochondrial tryptophanyl-tRNA synthetase gene) that is responsible for reduced cardiac angiogenesis (Wang et al. 2016) and impaired brown adipose tissue (BAT) function (Pravenec et al. 2017), and in Cd36 (fatty acid translocase gene) that predisposes SHR to insulin resistance and hypertension (Aitman et al. 1999, Pravenec et al. 2008) and affects BAT metabolism (Pravenec et al. 2018). The available SHR-Endog, SHR-Wars2 and SHR-Cd36 transgenic lines with wild type genes could be crossed with different conplastic strains to analyze mtDNA x nuclear DNA interactions. Conplastic strains could be also crossed with SHR lines with knockout of nuclear genes that code for mitochondrial proteins such as in the SHR-Usmg $5^{-/}$, SHR-Tmem $70^{+/-}$or SHR-Tert ${ }^{-/}$strains (Pravenec, Houštěk, Mráček et al. unpublished results). Finally, these results should serve to motivate future studies of the role of naturally occurring variation of mtDNA in the pathogenesis of cardiometabolic traits in humans.

\section{Conflict of Interest}

There is no conflict of interest.

\section{Acknowledgements}

This work was supported by grants from the Czech Science Foundation (19-10354S, 18-03207S, and 17-07748S), from the Charles University Institutional Research Fund (no. SVV-260571/2020) and by the Ministry of Health of the Czech Republic - conceptual development of research organisations ("Institute for Clinical and Experimental Medicine - IKEM, IN 00023001") and AV21 strategy project "QUALITAS Wellbeing in health and disease.

\section{References}

AITMAN TJ, GLAZIER AM, WALLACE CA, COOPER LD, NORSWORTHY PJ, WAHID FN, AL-MAJALI KM, TREMBLING PM, MANN CJ, SHOULDERS CC, GRAF D, ST LEZIN E, KURTZ TW, KREN V, PRAVENEC M, IBRAHIMI A, ABUMRAD NA, STANTON LW, SCOTT J: Identification of Cd36 (Fat) as an insulin-resistance gene causing defective fatty acid and glucose metabolism in hypertensive rats. Nat Genet, 21: 76-83, 1999. https://doi.org/10.1038/5013

ALCOLADO JC, LAJI K, GILL-RANDALL R: Maternal transmission of diabetes. Diabet Med 19: 89-98, 2002. https://doi.org/10.1046/j.1464-5491.2002.00675.x 
AW WC, TOWARNICKI SG, MELVIN RG, YOUNGSON NA, GARVIN MR, HU Y, NIELSEN S, THOMAS T, PICKFORD R, BUSTAMANTE S, VILA-SANJURJO A, SMYTH GK, BALLARD JWO: Genotype to phenotype: Diet-by-mitochondrial DNA haplotype interactions drive metabolic flexibility and organismal fitness. PLoS Genet 14: e1007735, 2018. https://doi.org/10.1371/journal.pgen.1007735

CYPROVÁ M, BENÁK D, HLAVÁČKOVÁ M, ŠILHAVÝ J, PRAVENEC M, KOLÁŘ F, NECKÁŘ J: Cardiac ischemic tolerance of spontaneously hypertensive rats with replaced mitochondrial DNA: Effect of adaptation to chronic hypoxia. J Mol Cell Cardiol 120 (Suppl. 1): 5, 2018. https://doi.org/10.1016/j.yjmcc.2018.05.027

DUNHAM-SNARY KJ, SANDEL MW, SAMMY MJ, WESTBROOK DG, XIAO R, MCMONIGLE RJ, RATCLIFFE WF, PENN A, YOUNG ME, BALLINGER SW: Mitochondrial - nuclear genetic interaction modulates whole body metabolism, adiposity and gene expression in vivo. EBioMedicine 36: 316-328, 2018. https://doi.org/10.1016/j.ebiom.2018.08.036

GOIOS A, PEREIRA L, BOGUE M, MACAULAY V, AMORIM A: mtDNA phylogeny and evolution of laboratory mouse strains. Genome Res 17: 293-298, 2007. https://doi.org/10.1101/gr.5941007

HAHNOVÁ K, BRABCOVÁ I, NECKÁŘ J, WEISSOVA R, SVATOŇOVÁ A, NOVÁKOVÁ O, ŽURMANOVÁ J, KALOUS M, ŠILHAVY J, PRAVENEC M, KOLÁŘ F, NOVOTNÝ J: Beta-Adrenergic signaling, monoamine oxidase A and antioxidant defence in the myocardium of SHR and SHR-mtBN conplastic rat strains: the effect of chronic hypoxia. J Physiol Sci 68: 441-454, 2018. https://doi.org/10.1007/s12576-017$\underline{0546-8}$

HOUŠTEK J, HEJZLAROVÁ K, VRBACKÝ M, DRAHOTA Z, LANDA V, ZÍDEK V, MLEJNEK P, ŠIMÁKOVÁ M, ŠILHAVÝ J, MIKŠÍK I, KAZDOVÁ L, OLIYARNYK O, KURTZ T, PRAVENEC M: Nonsynonymous variants in $\mathrm{mt}-\mathrm{Nd} 2$, mt-Nd4, and $\mathrm{mt}-\mathrm{Nd} 5$ are linked to effects on oxidative phosphorylation and insulin sensitivity in rat conplastic strains. Physiol Genomics 44: 487-494, 2012. https://doi.org/10.1152/physiolgenomics.00156.2011

HOUŠTĚK J, VRBACKÝ M, HEJZLAROVÁ K, ZÍDEK V, LANDA V, ŠILHAVÝ J, ŠIMÁKOVÁ M, MLEJNEK P, KAZDOVÁ L, MIKŠÍK I, NECKÁŘ J, PAPOUŠEK F, KOLÁŘ F, KURTZ TW, PRAVENEC M: Effects of mtDNA in SHR-mtF344 versus SHR conplastic strains on reduced OXPHOS enzyme levels, insulin resistance, cardiac hypertrophy, and systolic dysfunction. Physiol Genomics 46: 671-678, 2014. https://doi.org/10.1152/physiolgenomics.00069.2014

KESTERSON RA, JOHNSON LW, LAMBERT LJ, VIVIAN JL, WELCH DR, BALLINGER SW: Generation of mitochondrial-nuclear exchange mice via pronuclear transfer. Bio Protoc 6: e1976, 2016. https://doi.org/10.21769/BioProtoc.1976

KRAJA AT, LIU C, FETTERMAN JL, GRAFF M, HAVE CT, GU C, YANEK LR, FEITOSA MF, ARKING DE, CHASMAN DI, YOUNG K, LIGTHART S, HILL WD, WEISS S, LUAN J, GIULIANINI F, LI-GAO R, HARTWIG FP, LIN SJ, WANG L, RICHARDSON TG, YAO J, FERNANDEZ EP, GHANBARI M, WOJCZYNSKI MK, LEE WJ, ARGOS M, ARMASU SM, BARVE RA, RYAN KA, AN P, et al.: Associations of mitochondrial and nuclear mitochondrial variants and genes with seven metabolic traits. Am J Hum Genet 104: 112-138, 2019. https://doi.org/10.1016/j.ajhg.2018.12.001

KUMARASAMY S, GOPALAKRISHNAN K, SHAFTON A, NIXON J, THANGAVEL J, FARMS P, JOE B: Mitochondrial polymorphisms in rat genetic models of hypertension. Mamm Genome 21: 299-306, 2010. https://doi.org/10.1007/s00335-010-9259-5

KUMARASAMY S, GOPALAKRISHNAN K, ABDUL-MAJEED S, PARTOW-NAVID R, FARMS P, JOE B: Construction of two novel reciprocal conplastic rat strains and characterization of cardiac mitochondria. Am J Physiol Heart Circ Physiol 304: H22-32, 2013. https://doi.org/10.1152/ajpheart.00534.2012-

LATORRE-PELLICER A, MORENO-LOSHUERTOS R, LECHUGA-VIECO AV, SÁNCHEZ-CABO F, TORROJA C, ACÍN-PÉREZ R, CALVO E, AIX E, GONZÁLEZ-GUERRA A, LOGAN A, BERNAD-MIANA ML, ROMANOS E, CRUZ R, COGLIATI S, SOBRINO B, CARRACEDO Á, PÉREZ-MARTOS A, FERNÁNDEZ-SILVA P, RUÍZ-CABELLO J, MURPHY MP, FLORES I, VÁZQUEZ J, ENRÍQUEZ JA: Mitochondrial and nuclear DNA matching shapes metabolism and healthy ageing. Nature 535: 561-565, 2016. https://doi.org/10.1038/nature18618 
LOTT MT, LEIPZIG JN, DERBENEVA O, XIE HM, CHALKIA D, SARMADY M, PROCACCIO V, WALLACE DC: mtDNA variation and analysis using mitomap and mitomaster. Curr Protoc Bioinformatics 44: 1.23. 1-1.23.26, 2013. https://doi.org/10.1002/0471250953.bi0123s44

MAROM S, FRIGER M, MISHMAR D: MtDNA meta-analysis reveals both phenotype specificity and allele heterogeneity: a model for differential association. Sci Rep 7: 43449, 2017. https://doi.org/10.1038/srep43449

MCDERMOTT-ROE C, YE J, AHMED R, SUN XM, SERAFÍN A, WARE J, BOTTOLO L, MUCKETT P, CAÑAS X, ZHANG J, ROWE GC, BUCHAN R, LU H, BRAITHWAITE A, MANCINI M, HAUTON D, MARTÍ R, GARCÍA-ARUMÍ E, HUBNER N, JACOB H, SERIKAWA T, ZIDEK V, PAPOUSEK F, KOLAR F, CARDONA M, RUIZ-MEANA M, GARCÍA-DORADO D, COMELLA JX, FELKIN LE, BARTON PJ, ARANY Z, PRAVENEC M, PETRETTO E, SANCHIS D, COOK SA: Endonuclease G is a novel determinant of cardiac hypertrophy and mitochondrial function. Nature 478: 114-118, 2011. https://doi.org/10.1038/nature10490

MISHMAR D, RUIZ-PESINI E, GOLIK P, MACAULAY V, CLARK AG, HOSSEINI S, BRANDON M, EASLEY K, CHEN E, BROWN MD, SUKERNIK RI, OLCKERS A, WALLACE DC: Natural selection shaped regional mtDNA variation in humans. Proc Natl Acad Sci U S A 100: 171-176, 2003. https://doi.org/10.1073/pnas.0136972100

MITCHELL SL, HALL JB, GOODLOE RJ, BOSTON J, FARBER-EGER E, PENDERGRASS SA, BUSH WS, CRAWFORD DC: Investigating the relationship between mitochondrial genetic variation and cardiovascularrelated traits to develop a framework for mitochondrial phenome-wide association studies. BioData Min 7: 6, 2014. https://doi.org/10.1186/1756-0381-7-6

NECKÁŘ J, SVATOŇOVÁ A, WEISSOVÁ R, DRAHOTA Z, ZAJIČCOVÁ P, BRABCOVÁ I, KOLÁŘ D, ALÁNOVÁ P, VAŠINOVÁ J, ŠILHAVÝ J, HLAVÁČKOVÁ M, TAUCHMANNOVÁ K, MILEROVÁ M, OŠŤÁDAL B, ČERVENKA L, ŽURMANOVÁ J, KALOUS M, NOVÁKOVÁ O, NOVOTNÝ J, PRAVENEC M, KOLÁR̆ F: Selective replacement of mitochondrial DNA increases the cardioprotective effect of chronic continuous hypoxia in spontaneously hypertensive rats. Clin Sci (Lond) 131: 865-881, 2017. https://doi.org/10.1042/CS20170083

NEDVĚDOVÁ I, KOLÁŘ D, ELSNICOVÁ B, HORNÍKOVÁ D, NOVOTNÝ J, KALOUS M, PRAVENEC M, NECKÁŘ J, KOLÁ̌̌ F, ŽURMANOVÁ JM: Mitochondrial genome modulates myocardial Akt/Glut/HK salvage pathway in spontaneously hypertensive rats adapted to chronic hypoxia. Physiol Genomics 50: 532-541, 2018. https://doi.org/10.1152/physiolgenomics.00040.2017

NEDVĚDOVÁ I, KOLÁŘ D, NECKÁŘ J, KALOUS M, PRAVENEC M, ŠILHAVÝ J, KOŘENKOVÁ V, KOLÁŘ F, ŽURMANOVÁ JM: Cardioprotective regimen of adaptation to chronic hypoxia diversely alters myocardial gene expression in SHR and SHR-mtBN conplastic rat strains. Front Endocrinol (Lausanne) 9: 809, 2019. https://doi.org/10.3389/fendo.2018.00809

PRAVENEC M, HYAKUKOKU M, HOUŠTĚK J, ZÍDEK V, LANDA V, MLEJNEK P, MIKŠÍK I, DUDOVÁMOTHEJZÍKOVÁ K, PECINA P, VRBACKÝ M, DRAHOTA Z, VOJTÍŠKOVÁ A, MRÁČEK T, KAZDOVÁ L, OLIYARNYK O, WANG J, HO C, QI N, SUGIMOTO K, KURTZ T: Direct linkage of mitochondrial genome variation to risk factors for type 2 diabetes in conplastic strains. Genome Res 17: 1319-1326, 2007. https://doi.org/10.1101/gr.6548207

PRAVENEC M, CHURCHILL PC, CHURCHILL MC, VIKLICKÝ O, KAZDOVÁ L, AITMAN TJ, PETRETTO E, HÜBNER N, WALLACE CA, ZIMDAHL H, ZÍDEK V, LANDA V, DUNBAR J, BIDANI A, GRIFFIN K, QI N, MAXOVÁ M, KŘEN V, MLEJNEK P, WANG J, KURTZ TW: Identification of renal Cd36 as a determinant of blood pressure and risk for hypertension. Nat Genet 40: 952-954, 2008. https://doi.org/10.1038/ng.164

PRAVENEC M, KŘEN V, LANDA V, MLEJNEK P, MUSILOVÁ A, ŠILHAVÝ J, ŠIMÁKOVÁ M, ZÍDEK V: Recent progress in the genetics of spontaneously hypertensive rats. Physiol Res 63 (Suppl 1): S1-S8, 2014. https://doi.org/10.33549/physiolres. 932622 
PRAVENEC M, ZÍDEK V, LANDA V, MLEJNEK P, ŠILHAVÝ J, ŠIMÁKOVÁ M, TRNOVSKÁ J, ŠKOP V, MARKOVÁ I, MALÍNSKÁ H, HÜTTL M, KAZDOVÁ L, BARDOVÁ K, TAUCHMANNOVÁ K, VRBACKÝ M, NƯSKOVÁ H, MRÁČEK T, KOPECKÝ J, HOUŠTĚK J: Mutant Wars2 gene in spontaneously hypertensive rats impairs brown adipose tissue function and predisposes to visceral obesity. Physiol Res 66: 917-924, 2017. https://doi.org/10.33549/physiolres.933811

PRAVENEC M, SABA LM, ZÍDEK V, LANDA V, MLEJNEK P, ŠILHAVÝ J, ŠIMÁKOVÁ M, STRNAD H, TRNOVSKÁ J, ŠKOP V, HÜTTL M, MARKOVÁ I, OLIYARNYK O, MALÍNSKÁ H, KAZDOVÁ L, SMITH H, TABAKOFF B: Systems genetic analysis of brown adipose tissue function. Physiol Genomics 50: 52-66, 2018. https://doi.org/10.1152/physiolgenomics.00091.2017

RUIZ-PESINI E, MISHMAR D, BRANDON M, PROCACCIO V, WALLACE DC: Effects of purifying and adaptive selection on regional variation in human mtDNA. Science 303: 223-226, 2004. https://doi.org/10.1126/science.1088434

SAXENA R, DE BAKKER PI, SINGER K, MOOTHA V, BURTT N, HIRSCHHORN JN, GAUDET D, ISOMAA B, DALY MJ, GROOP L, ARDLIE KG, ALTSHULER D: Comprehensive association testing of common mitochondrial DNA variation in metabolic disease. Am J Hum Genet 79: 54-61, 2006. https://doi.org/10.1086/504926

SCHLICK NE, JENSEN-SEAMAN MI, ORLEBEKE K, KWITEK AE, JACOB HJ, LAZAR J: Sequence analysis of the complete mitochondrial DNA in 10 commonly used inbred rat strains. Am J Physiol Cell Physiol 291: C1183-1192, 2006. https://doi.org/10.1152/ajpcell.00234.2006

SONG S, PURSELL ZF, COPELAND WC, LONGLEY MJ, KUNKEL TA, MATHEWS CK. DNA precursor asymmetries in mammalian tissue mitochondria and possible contribution to mutagenesis through reduced replication fidelity Proc Natl Acad Sci U S A 102: 4990-4995, 2005. https://doi.org/10.1073/pnas.0500253102

SUN F, CUI J, GAVRAS H, SCHWARTZ F: A novel class of tests for the detection of mitochondrial DNA-mutation involvement in diseases. Am J Hum Genet 72: 1515-1526, 2003. https://doi.org/10.1086/375656

WANG M, SIPS P, KHIN E, ROTIVAL M, SUN X, AHMED R, WIDJAJA AA, SCHAFER S, YUSOFF P, CHOKSI PK, KO NS, SINGH MK, EPSTEIN D, GUAN Y, HOUŠTĚK J, MRACEK T, NUSKOVA H, MIKELL B, TAN J, PESCE F, KOLAR F, BOTTOLO L, MANCINI M, HUBNER N, PRAVENEC M, PETRETTO E, MACRAE C, COOK SA: Wars2 is a determinant of angiogenesis. Nat Commun 7: 12061, 2016. https://doi.org/10.1038/ncomms12061

YU X, GIMSA U, WESTER-ROSENLÖF L, KANITZ E, OTTEN W, KUNZ M, IBRAHIM SM: Dissecting the effects of mtDNA variations on complex traits using mouse conplastic strains. Genome Res 19: 159-165, 2009. https://doi.org/10.1101/gr.078865.108 